\title{
Andrographolide sensitizes human renal carcinoma cells to TRAIL-induced apoptosis through upregulation of death receptor 4
}

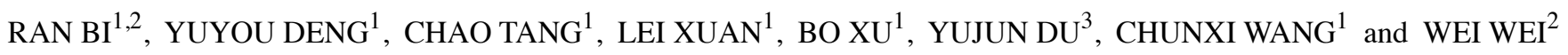 \\ ${ }^{1}$ Department of Urology, The First Hospital of Jilin University, Changchun, Jilin 130021; \\ ${ }^{2}$ Key Laboratory of Organ Regeneration and Transplantation of The Ministry of Education, Institute of Translational Medicine, \\ Institute of Virology and AIDS Research, The First Hospital of Jilin University, Changchun, Jilin 130061; \\ ${ }^{3}$ Department of Nephrology, First Hospital of Jilin University, Changchun, Jilin 130021, P.R. China
}

Received February 3, 2020; Accepted July 23, 2020

DOI: 10.3892/or.2020.7737

\begin{abstract}
Tumor necrosis factor-related apoptosis-inducing ligand (TRAIL) selectively induces apoptosis in cancer cells, with minimal toxicity to normal tissues. However, accumulating evidence suggests that certain cancer types are insensitive to TRAIL signaling. The aim of this study was to identify an effective combination regimen, which can overcome TRAIL resistance in renal cancer cell. Herein, we found that human renal carcinoma cells (RCCs) are widely resistant to TRAIL-mediated growth inhibition and subsequently identified that andrographolide (Andro), a major constituent of Andrographis paniculate, an annual herbaceous plant in the family Acanthaceae, counteracts TRAIL resistance in RCCs. Combined treatment with TRAIL and Andro suppressed cell viability as determined by MTS and proliferation as determined by EdU in a dose-dependent manner and inactivated the clonogenic and migration ability of RCCs. Andro significantly enhances TRAIL-mediated cell cycle arrest at the G2/M phase as determined by flow cytometry and senescence. Moreover, Andro restored TRAIL signaling, which in turns activated pro-apoptosis caspases as determined by immunoblot assay. The TRAIL receptor, death receptor (DR)4, but not DR5, was found to be significantly upregulated in Andro-treated RCC
\end{abstract}

Correspondence to: Dr Chunxi Wang, Department of Urology, The First Hospital of Jilin University, 71 Xinmin Street, Changchun, Jilin 130021, P.R. China

E-mail: chunxi_wang@126.com

Dr Wei Wei, Key Laboratory of Organ Regeneration and Transplantation of The Ministry of Education, Institute of Translational Medicine, Institute of Virology and AIDS Research, The First Hospital of Jilin University, 71 Xinmin Street, Changchun, Jilin 130061, P.R. China

E-mail: wwei6@jlu.edu.cn

Key words: andrographolide, TRAIL, renal cell carcinoma, sensitizer, death receptor 4 cells, which contributed to the role of Andro as a TRAIL sensitizer. The present study demonstrated that the combined treatment of Andro and TRAIL has potential therapeutic value against renal cancer.

\section{Introduction}

Renal cell carcinoma (RCC) is one of the most commonly diagnosed human malignant neoplasms with more than 300,000 new patients diagnosed worldwide each year (1). The major type of kidney tumor $(80-90 \%)$ originates from the epithelial lining of the proximal convoluted tubules and exhibits highly vascularized and metastatic characteristics (2). To date, the primary therapy for localized RCC is surgery (radical nephrectomy and nephron-sparing surgery), while for unresectable and metastatic RCC, the therapeutic options remain limited (3-5). RCC is sensitive to neither traditional chemotherapy nor radiation therapy (6). However, the existing therapies remain ineffective against metastatic and unresectable RCC. Therefore, exploring effective and safe strategies for the treatment of RCCs is crucial.

Tumor necrosis factor-related apoptosis-inducing ligand (TRAIL), a member of the tumor necrosis factor (TNF) family, is an optimal anticancer agent (7). The ability of TRAIL to induce apoptosis depends on the interaction of TRAIL and its membrane receptors death receptor (DR)4 and DR5 (named as TRAIL-R1 and TRAIL-R2) (8). Upon ligand stimulation, DR4 and DR5 bind Fas-associated death domain protein (FADD) through the death domain, which results in the formation of the death-inducing signaling complex (DISC). Caspase 8 is then recruited to DISC where it initiates the downstream apoptotic cascade. Activation of caspase 8 induces apoptosis via two well-elucidated apoptotic pathways: The extrinsic pathway (stimulating the effector caspases 3,6, and 7) and the intrinsic-mitochondrial pathway [stimulating Bax and Bak, and releasing mitochondrial cytochrome $c$ and mitochondrial-derived activator of caspase (Smac)] (9-11). As death receptors, DR4 and DR5 are normally upregulated in tumor cells, thus the TRAIL signaling pathway can be an optimal target for cancer therapy (12-14). Accumulating evidence 
from basic and clinical studies indicates that various cancer types are not sensitized to TRAIL-induced apoptosis $(15,16)$. TRAIL-based drug development has attracted significant interest to identify an effective combination regimen, which can overcome TRAIL resistance in cancer cells.

In renal cancer, a cancer type highly resistant to chemotherapy, the identification of specific agents that are able to sensitize TRAIL-induced apoptosis of unresponsive renal carcinoma cells holds the utmost importance for the targeted treatment of renal cancer. In the present study, our data showed that andrographolide (Andro), a major constituent of Andrographis paniculate, an annual herbaceous plant in the family Acanthaceae, remarkably improved the sensitivity of RCC cells to TRAIL-induced growth inhibition. The combined treatment stimulated caspase-dependent apoptosis, and enhanced DR4 expression. Our study provides proof-of-concept evidence for the clinical application of this traditional anti-inflammatory medical agent, andrographolide, in the treatment of renal cancers.

\section{Materials and methods}

Cell culture and treatments. The RCC cell lines 786-0, OS-RC-2, and ACHN were purchased from the Type Culture Collection of the Chinese Academy of Sciences (Shanghai, China). 786-0 cells were cultured in RPMI-1640 medium (HyClone; Cytiva). OS-RC-2 and ACHN cells were cultured in the DMEM medium (HyClone; Cytiva). All media were supplemented with $10 \%$ fetal bovine serum (FBS) (Biological Industries, USA) and penicillin/streptomycin solution. All cells were cultured under standard incubator conditions $\left(37^{\circ} \mathrm{C}, 5 \% \mathrm{CO}_{2}\right)$.

Chemicals, reagents, and antibodies. Andrographolide (MedChemExpress, MCE) was dissolved in DMSO at $10 \mathrm{mmol} / \mathrm{l}$ as a stock solution, and recombinant human TRAIL (R\&D Systems, Inc.) was prepared in PBS containing $0.1 \%$ bovine serum albumin at $20 \mu \mathrm{g} / \mathrm{ml}$. Z-VAD (HY-16658) and Necrostatin-1 (HY-15760) were purchased from MCE. Antibodies used in this study were as follows: Phospho-HistoneH2A.X (product \#9718), PARP1 (product \#9532), DR4 (product \#42533), caspase 9 (product \#9502), caspase 8 (product \#4790), GAPDH (product \#51332) (from Cell Signaling Technology, Inc.), Bax (cat. \#633601, BioLegend), DR5 (LM11912, Novus, USA), $\beta$-actin (ab8227, Abcam), anti-rabbit IgG (product \#7054) and anti-mouse IgG (product \#7056) (from Cell Signaling Technology, Inc.).

Cell viability assay. Cell viability was assessed by measuring the formazan production following the addition of 3-(4,5-dimethylthiazol-2-yl)-5-(3-carboxymethoxyphenyl)-2(4-sulphop-henyl)-2H-tetrazolium, inner salt (MTS) (Promega Corp.). Approximately 5,000 cells/well were seeded in a 96-well plate and incubated at $37^{\circ} \mathrm{C}$ in a $5 \% \mathrm{CO}_{2}$ incubator for $24 \mathrm{~h}$. The cells were incubated in a medium containing $20 \mu \mathrm{l}$ MTS for $3 \mathrm{~h}$ at $37^{\circ} \mathrm{C}$ post treatment under different conditions for $24 \mathrm{~h}$. Absorbance was detected using a BioTek ELISA reader (BioTek Instruments, Inc.) at a wavelength of $490 \mathrm{~nm}$.

Cell proliferation assay. We used EdU (5-ethynyl-2'deoxyuridine) and colony formation assays to evaluate the effect of Andro and/or TRAIL on cell proliferation. For the EdU Assay, $2 \times 10^{5}$ cells/well were seeded in a 12-well plate, treated under Andro and/or TRAIL for $24 \mathrm{~h}$, and then, cell proliferation was determined using BeyoClick EdU cell proliferation kit (Beyotime Biotech Inc.) according to the manufacturer's instructions. Images (x400 magnification) of the cells were acquired on a confocal microscope using OLYMPUS cellSens Standard software (Olympus).

For the colony formation assays, 200 cells/well were seeded in a 6-well plate in $2 \mathrm{ml}$ of medium, treated under different conditions, and subjected to growth for 12 days. After 12 days of incubation, the cells were washed once with cold phosphate-buffered saline (PBS). Then, $4 \%$ paraformaldehyde was used to fix the cells for $20 \mathrm{~min}$. Cells were then stained with $0.1 \%$ crystal violet solution for $15 \mathrm{~min}$ at $25^{\circ} \mathrm{C}$, and then washed with water thrice and air-dried for counting using an inverted microscope (x100 magnification), where cell colonies ( $>50$ cells) were counted. All experiments were repeated thrice.

Cell migration assay. For cell migration, $2 \times 10^{5}$ cells/well were seeded in a 6-well plate and incubated in an incubator. When the cells reached $90 \%$ confluence, straight scratches were made by using a sterile $200-\mu$ l pipette tip and the cells were then washed thrice with PBS. Then the cells were incubated in an incubator with serum-free medium containing Andro or/and TRAIL or DMSO for $24 \mathrm{~h}$. An inverted microscope (x100 magnification) was used to monitor cell migration at $0,6,12,18$ and $24 \mathrm{~h}$ post scratching. Images of cells were acquired on a confocal microscope using OLYMPUS cellSens Standard software. Data were analyzed with Image J software (version 1.8.0, National Institutes of Health, Bethesda, MD, USA).

Flow cytometric analysis. For cell cycle analysis, cells treated under different conditions for $24 \mathrm{~h}$ were detached from the 6-well culture plates, washed twice with ice-cold PBS, and pelleted by centrifugation at $1,000 \mathrm{x}$. The cells were then suspended in $75 \%$ ethanol overnight at $-20^{\circ} \mathrm{C}$. Following an overnight suspension, cells were centrifuged at $1,000 \mathrm{x} \mathrm{g}$ for $5 \mathrm{~min}$ and washed twice with ice-cold PBS. The cell pellets were resuspended in buffer containing PI (propidium iodide) and RNase for $1 \mathrm{~h}$ in the dark at $37^{\circ} \mathrm{C}$, and the cell cycle distribution was examined by flow cytometry (BD Bioscience) after filtration.

Apoptotic cells were identified and quantified by using the Annexin V-FITC apoptosis detection kit (KeyGENBioTECH). After treatment under different conditions for $24 \mathrm{~h}$, the cells were digested and collected with trypsin solution without EDTA, which were then washed twice with PBS and then centrifuged at $1,200 \times \mathrm{g}$ for $5 \mathrm{~min}$ to collect the cells. In the next step, the cells were re-suspended in binding buffer and incubated with Annexin V-FITC and PI for $15 \mathrm{~min}$ in the dark at $37^{\circ} \mathrm{C}$. A fluorescence-activated cell sorting (FACS) flow cytometer (BD Bioscience) was used to analyze cell apoptosis.

Cell senescence assay. Senescent cells were identified and quantified by Senescence $\beta$-Galactosidase staining kit (Cell Signaling Technology, Inc.). Following treatment under different conditions for $24 \mathrm{~h}$, the cells were washed with PBS, fixed by the fixative solution for $15 \mathrm{~min}$ at $25^{\circ} \mathrm{C}$, and determined using Senescence $\beta$-Galactosidase $(\mathrm{pH}=6.0)$ staining 
for $24 \mathrm{~h}$. An inverted microscope (x400 magnification) was used to monitor senescent cells and to count them. Images of the cells were acquired on a confocal microscope using OLYMPUS cellSens Standard software.

Immunoblot assay. Whole-cell extracts, which were treated under different conditions for the corresponding times, were separated by $12 \%$ sodium dodecyl sulfate polyacrylamide gel electrophoresis and electrophoretically transferred to nitrocellulose membranes (EMD Millipore), and 5-bromo-4-chloro-3-indolyl phosphate and nitro blue tetrazolium (EMD Millipore) were used to visualize the protein bands. Images of the western blotting were acquired on a scanner (Epson Perfection V330 Photo) using Scan-n-Stitch Deluxe software (version 1.1.9, Arcsoft).

siRNAs for the construction of knockdown cells. Synthetic siRNA [negative-control siRNA, DR4 siRNA, and DR5 siRNA] which can specifically knock down the TNFRSF10A (DR4) gene and TNFRSF10B (DR5) gene, were obtained from GenePharma (Shanghai, China). The cellular delivery of siRNA was performed using Lipofectamine 3000 (Thermo Fisher Scientific, Inc.), optimized using various siRNA concentrations, and evaluated by immunoblot assay. The siRNA sequences are listed in Table SI.

Data collection and bioinformatics analysis. We downloaded fragments per kilobase million (FPKM) values of RNA-sequencing profiles of RCC patients including 414 RCC tissues and 19 normal tissues from The Cancer Genome Atlas (TCGA) databse's official website (https://portal.gdc.cancer. gov/). RNA expression datasets were processed using the R software version 3.6.6 (https://www.r-project.org/).

Statistical analysis. Differences among test groups were analyzed by GraphPad Prism software (version 8.0; GraphPad Software Inc.). Data are expressed as the mean \pm standard deviations (SD). An unpaired two-tailed Student's t test was performed to detect statistical difference between two individual experimental groups. For multiple comparisons, statistical analyses were performed using one-way analysis of variance (ANOVA) and two-way ANOVA with Dunnett and Tukey post-test. $\mathrm{P}<0.05$ was considered to indicate a statistically significant difference.

\section{Results}

Andro sensitizes TRAIL-induced survival and proliferation inhibition in renal cancer cells. As DR4 and DR5 are canonical TRAIL receptors involved in its antitumor effects, we analyzed mRNA expression data of RCC patients from the TCGA database. We found that the mean DR5 mRNA expression in renal cancer tissues exceeded that in normal tissues, whereas a mild was found in DR4 between tumor and normal tissues (Fig. 1A). These data hinted that TRAIL signaling could be a potential target for renal cancer therapy. However, our experiments indicated that renal cancer 786-0, OS-RC-2, and ACHN cells were resistant to the TRAIL-mediated suppression even at an extremely high concentration $(200 \mathrm{ng} / \mathrm{ml})$, while our previous study demonstrated that the $50 \%$ inhibitory concentration $\mathrm{IC}_{50}$ value of TRAIL in bladder cancer T24 cells was $38.35 \mathrm{ng} / \mathrm{ml}$ (Fig. 1C-E) (17). As noted, andrographolide (Andro), a diterpene lactone $\left(\mathrm{C}_{20} \mathrm{H}_{30} \mathrm{O}\right)(\mathrm{Fig} .1 \mathrm{~B})$, represents a potential agonist for TRAIL therapy. The $\mathrm{IC}_{50}$ of Andro was $50.19 \mu \mathrm{M}$ in 786-0 cells, $45.32 \mu \mathrm{M}$ in OS-RC-2 cells, and $45.55 \mu \mathrm{M}$ in ACHN cells (Fig. 1C-E). Interestingly, cell viability of the RCC cell lines treated with the combination of Andro and TRAIL for $24 \mathrm{~h}$ was significantly decreased as compared with that of the cells treated with TRAIL or Andro alone (Fig. 1C-E).

Next, we evaluated the ability of Andro to sensitize TRAIL-mediated proliferation inhibition in RCC cells. As shown in Fig. 2B, TRAIL $(50 \mathrm{ng} / \mathrm{ml})$ or Andro $(5 \mu \mathrm{M}$ or $10 \mu \mathrm{M}$ ) alone mildly inhibited the growth rate of renal cancer cells. In contrast, Andro significantly sensitized 786-0 cells to TRAIL-mediated proliferation inhibition at a concentration of $5 \mu \mathrm{M}$. In agreement with this result, the morphological changes in treated RCC cells further supported that the combined treatment with TRAIL and Andro inhibited the survival and proliferation of 786-0 (Fig. 2A), OS-RC-2 (Fig. S1A) and ACHN cells (Fig. S2A) more potently than single-drug treatment. Furthermore, EdU cell proliferation assay showed that 786-0 cells treated with the combination of TRAIL and Andro proliferated much more slower than the cells exposed to single-drug treatment (Fig. 2C).

Andro promotes TRAIL-dependent inhibition of the clone formation and migration of renal cancer cells. Subsequently, we conducted clonogenic assays to determine the long-term anti-proliferative effects of Andro and TRAIL in invasive renal cancer cells. Our data indicated that the colony formation in case of cells treated with the combination of Andro and TRAIL was significantly (75\%) inhibited compared to that in cells treated with only Andro or TRAIL in 786-0 (Fig. 2D), OS-RC-2 (Fig. S1B) and ACHN cells (Fig. S2B) cells.

To determine whether Andro increases the ability of TRAIL to suppress RCC migration, we applied wound healing measurements as functional readings. The results indicated that TRAIL or Andro alone modestly $(<25 \%)$ decreased the migration of RCC 786-0 (Fig. 2E), OS-RC-2 (Fig. S1C) and ACHN cells (Fig. S2C) cells. However, there was an approximately 95\% decrease in RCC migration induced by the combined treatment of Andro and TRAIL. These findings demonstrated that Andro effectively enhanced the suppression of the growth and migration of renal cancer cells mediated by TRAIL.

Andro enhances TRAIL-induced G2 cell cycle arrest and senescence in renal cancer cells. To understand the mechanism through which the combined treatment of Andro and TRAIL inhibited cell proliferation, we investigated the effects of the indicated drugs on the cell cycle distribution of RCC cells, and demonstrated that TRAIL $(50 \mathrm{ng} / \mathrm{ml})$ or Andro $(5 \mu \mathrm{M})$ alone did not have a significant effect on cell cycle distribution. Yet, in the case of 786-0 cells treated with the same amounts of TRAIL and Andro significant cell cycle arrest at the G2 phase was triggered (Fig. 3A and B).

Moreover, RCC cells treated with a combination of Andro and TRAIL appeared larger, and flat morphological changes with time were exacerbated, which indicated that cell senescence was exacerbated. This was confirmed by the $\beta$-galactosidase staining assay (Fig. 3C and D). 
A

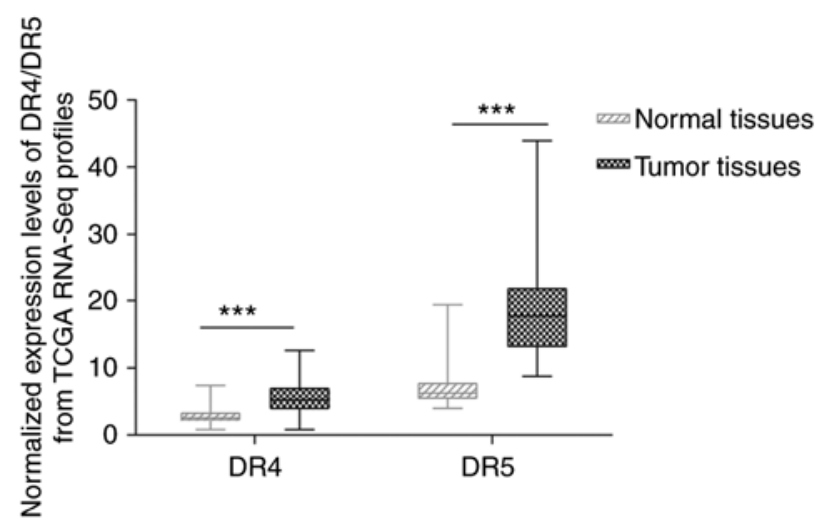

\author{
C
}

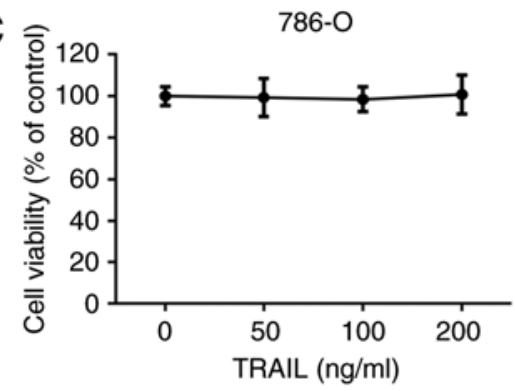

D

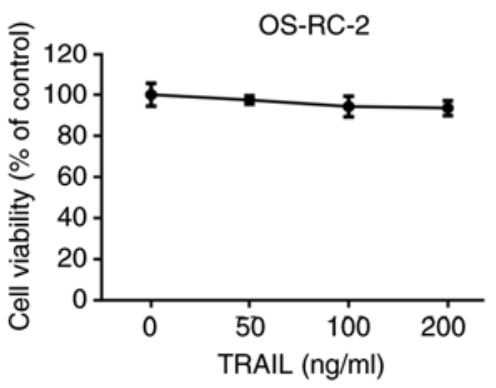

$\mathrm{E}$

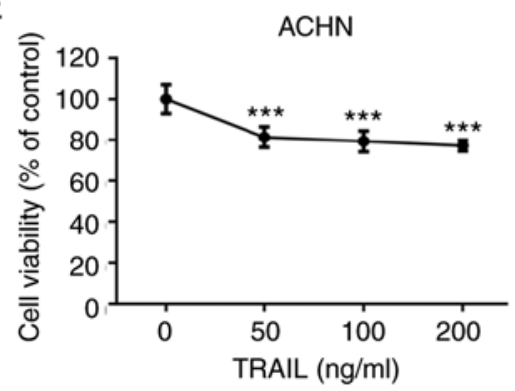

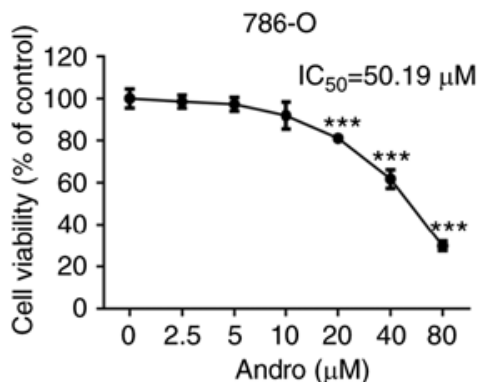

OS-RC-2
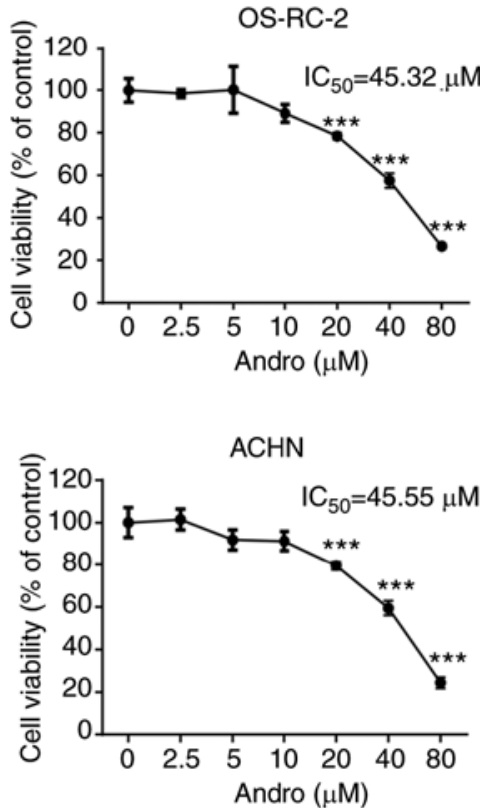

B<smiles>C=C1CC[C@]2(CO)[C@H](C)[C@](C)(O)CC[C@]2(C)[C@H]1CC=C1C(=O)OCC1O</smiles>
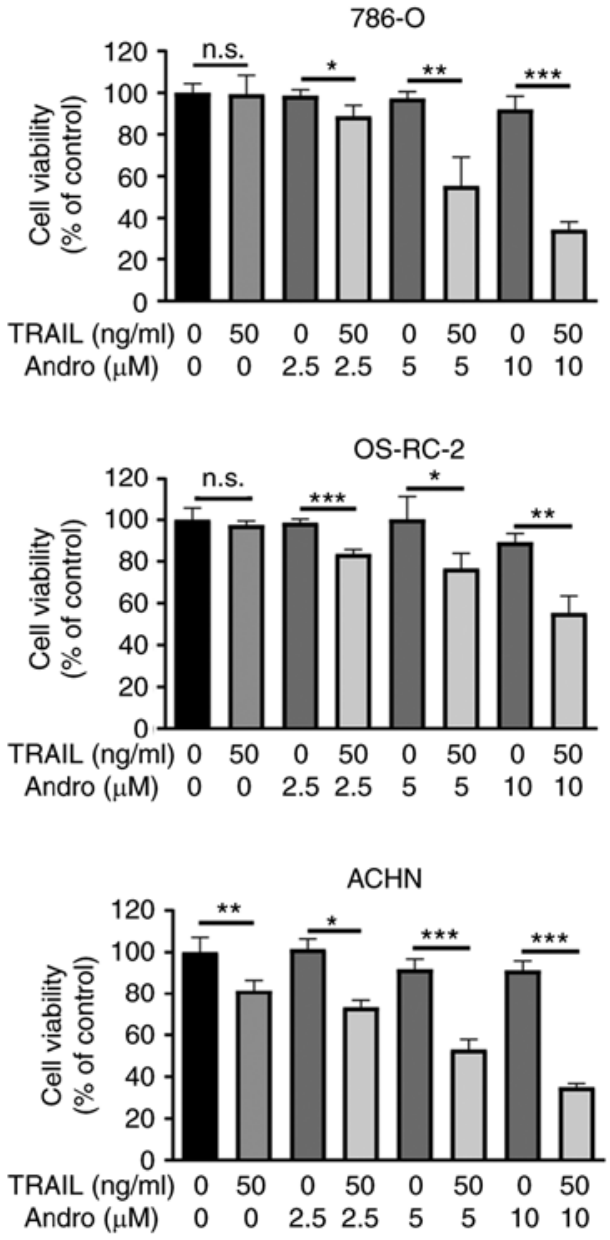

Figure 1. TRAIL combined with Andro inhibits RCC cell viability. (A) Normalized mRNA expression levels of DR4/DR5 in normal renal tissues and RCC tissues from TCGA RNA-Seq profiles. (B) Chemical structure of Andro. (C-E) Effects of TRAIL and Andro on the cell viability of 786-0 (C), OS-RC-2 (D) and ACHN (E) cells. Statistical analysis was carried out by one-way ANOVA and Dunnett's multiple comparisons test. Data are shown as mean \pm SD; n.s. (not significant), $\mathrm{P}>0.05 ;{ }^{*} \mathrm{P}<0.05,{ }^{* *} \mathrm{P}<0.01,{ }^{* * *} \mathrm{P}<0.001 ; \mathrm{n}=3$ ). Andro, andrographolide; TRAIL, tumor necrosis factor-related apoptosis-inducing ligand; TCGA, The Cancer Genome Atlas.

Combination of Andro and TRAIL triggers apoptosis in renal cancer cells. In RCC 786-0 cells treated with the combination of Andro and TRAIL, we observed apoptotic features, such as cell contraction, rounding, and floating. We then evaluated the roles of Andro in apoptosis progression using Annexin V-fluorescein isothiocyanate (FITC)/propidium iodide (PI)-labeled flow cytometry. Compared with groups that were solely treated with TRAIL $(4.07 \pm 0.29 \%)$ or Andro $(6.33 \pm 0.24 \%)$, the groups treated with their combination for $24 \mathrm{~h}$ exhibited $39.26 \pm 1.17 \%$ apoptosis (Fig. 4A).
Immunoblot assays were used to analyze changes in protein content in 786-0 cells treated with TRAIL and/or Andro. The results indicated that the combined treatment enhanced levels of cleaved-poly(ADP ribose) polymerase 1 (PARP1; $89 \mathrm{kDa})$, cleaved caspase $8(17 \mathrm{kDa})$, and cleaved caspase 9 (35 kDa). It also decreased full-length caspase 8 (60 kDa) and caspase $9(45 \mathrm{kDa})$ expression while increasing levels of apoptosis regulator Bax $(21 \mathrm{kDa})$, indicating caspase 8 activation and initiation of the apoptotic signal (Fig. 4B). We also noted that the levels of the phosphorylated form of $\mathrm{H} 2 \mathrm{AX}$ 
A

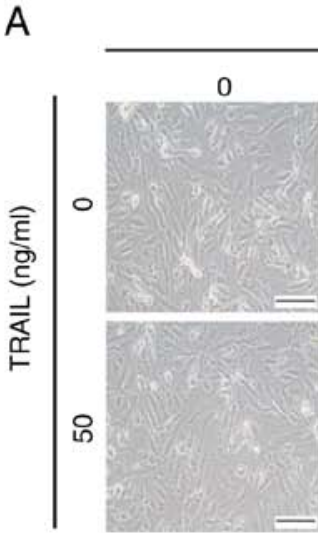

C
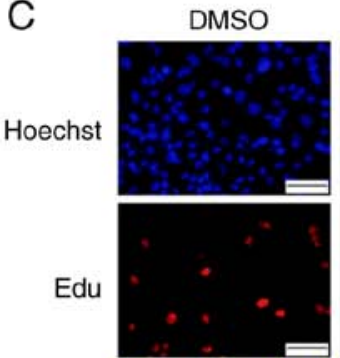

Overlay

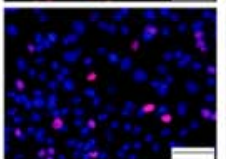

D
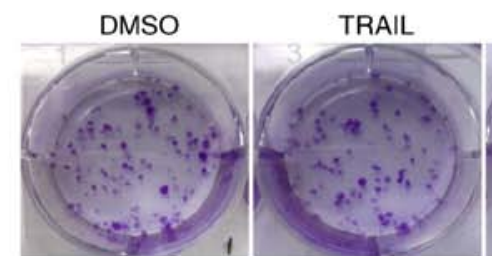

E

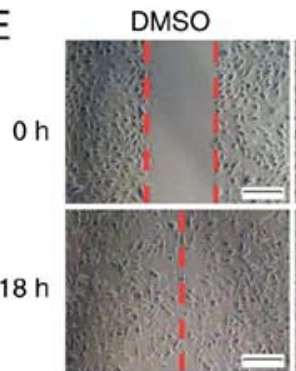

Andro $(\mu \mathrm{M})$
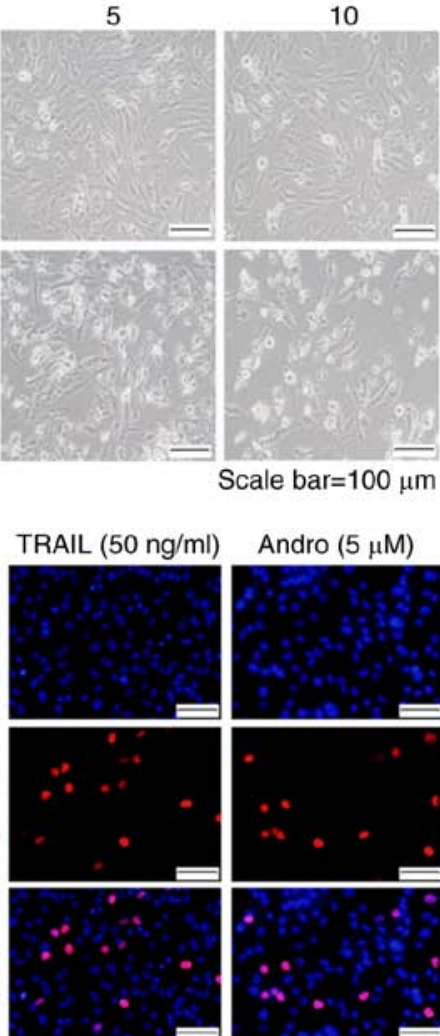

Andro $(5 \mu \mathrm{M})$
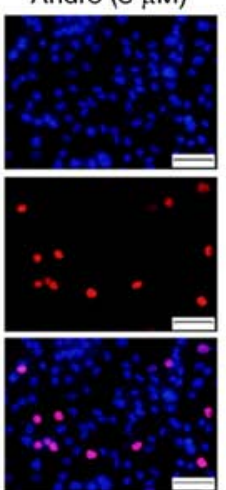

Andro

TRAIL
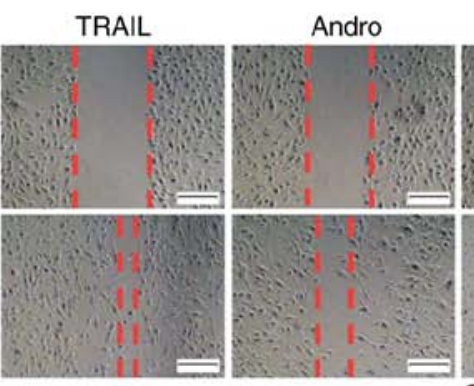
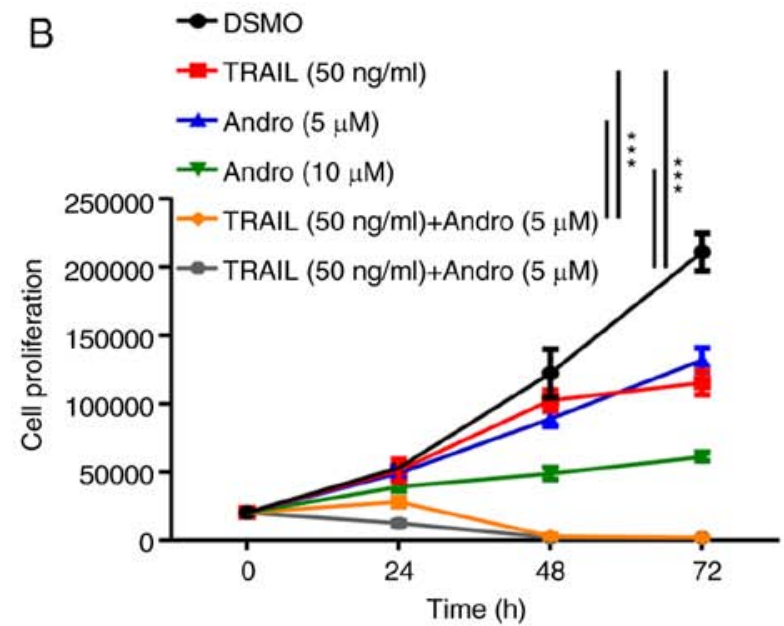

TRAIL+Andro
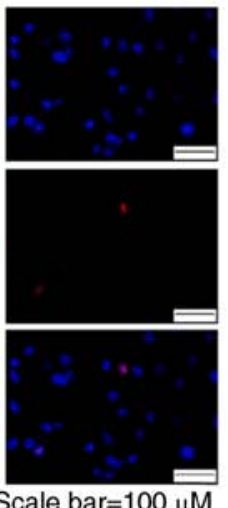

TRAIL+Andro

TRAIL+Andro
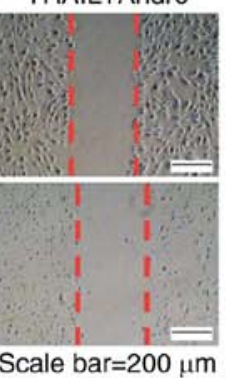
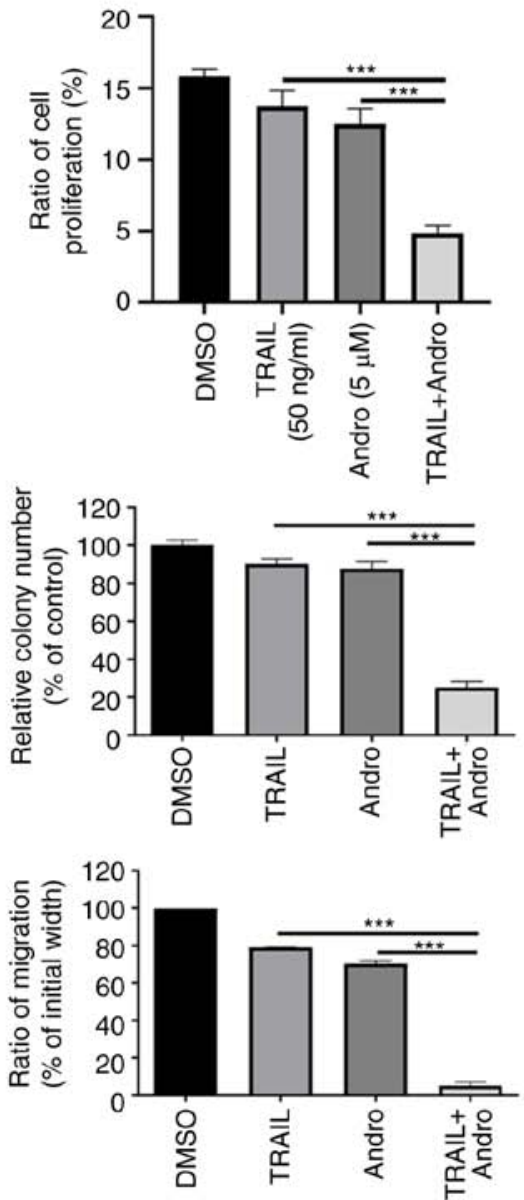

Figure 2. TRAIL combined with Andro inhibits the cell proliferation, colony formation, and migration of 786-0 cells. (A) Images (x200 magnification) show 786-0 cell morphology after treatment with various concentrations of TRAIL and/or Andro for $24 \mathrm{~h}$. (B) Cell proliferation of $786-0$ cells after treated with various concentrations of TRAIL and/or Andro for 24, 48 and $72 \mathrm{~h}$ (two-way ANOVA, Tukey). (C) Images (x200 magnification) show cells that were treated with TRAIL $(50 \mathrm{ng} / \mathrm{ml})$ and/or Andro $(5 \mu \mathrm{M})$ for $24 \mathrm{~h}$, and then proliferation was determined by BeyoClick EdU cell proliferation kit. Hoechst staining shows the entire nucleus, and EdU shows the nucleus which was proliferating. The histogram (right) shows the ratio of proliferation (one-way ANOVA, Tukey). (D) Effects of TRAIL $(50 \mathrm{ng} / \mathrm{ml})$ and Andro $(0.5 \mu \mathrm{M})$ on the clonogenic formation of $786-0$ cells. The histogram indicates the percentage of each group's clony number compared to the control group (one-way ANOVA, Tukey). (E) Images (x100 magnification) show the effects of TRAIL (50 ng/ml) and Andro (5 $\mu \mathrm{M}$ ) on the migratory ability of 786-0 cells. The histogram indicates the percentage of migration compared to the initial width (one-way ANOVA, Tukey). Data are shown as mean $\pm \mathrm{SD} ;{ }^{* * *} \mathrm{P}<0.001 ; \mathrm{n}=3$ ). Andro, andrographolide; TRAIL, tumor necrosis factor-related apoptosis-inducing ligand.

$(\gamma-\mathrm{H} 2 \mathrm{AX})$ were increased in Andro and TRAIL combined treated groups (Fig. 4B). We also showed that the combination therapy also potently induced apoptosis in other RCC cell lines (OSR-C and ACHN cells); supporting that Andro enhanced TRAIL-induced apoptosis independent of RCC cell type (Fig. S3).

Additionally, we found that RCC apoptosis induced by combined treatment was initiated by caspase-specific 
A

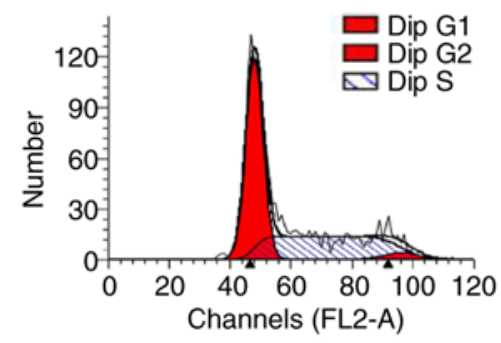

Andro

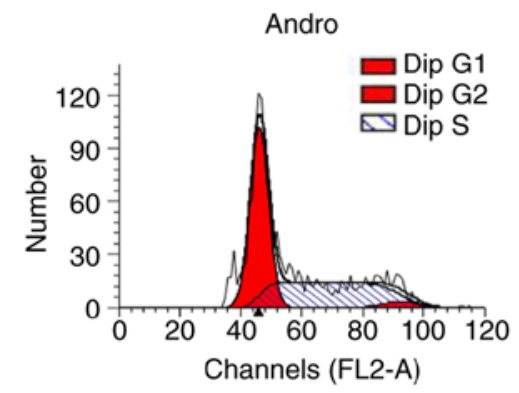

TRAIL
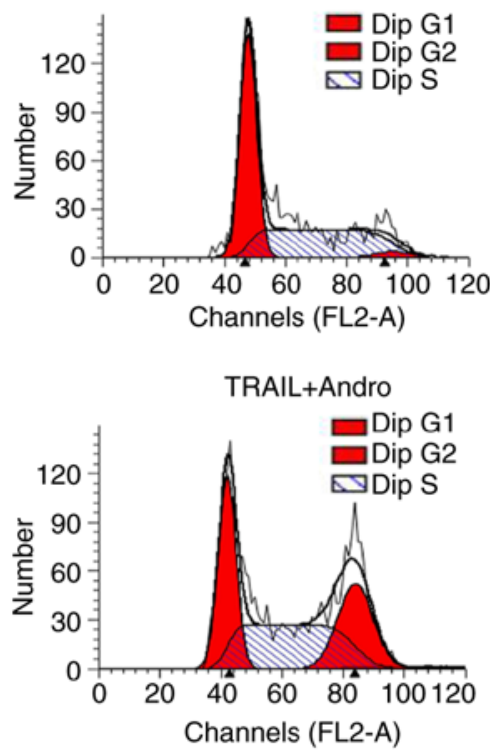

B

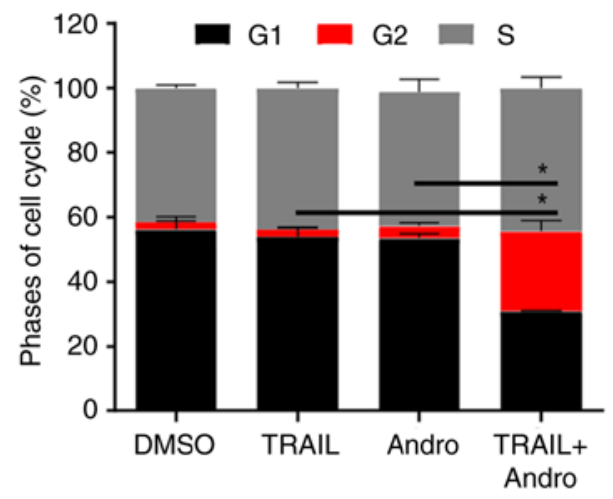

C

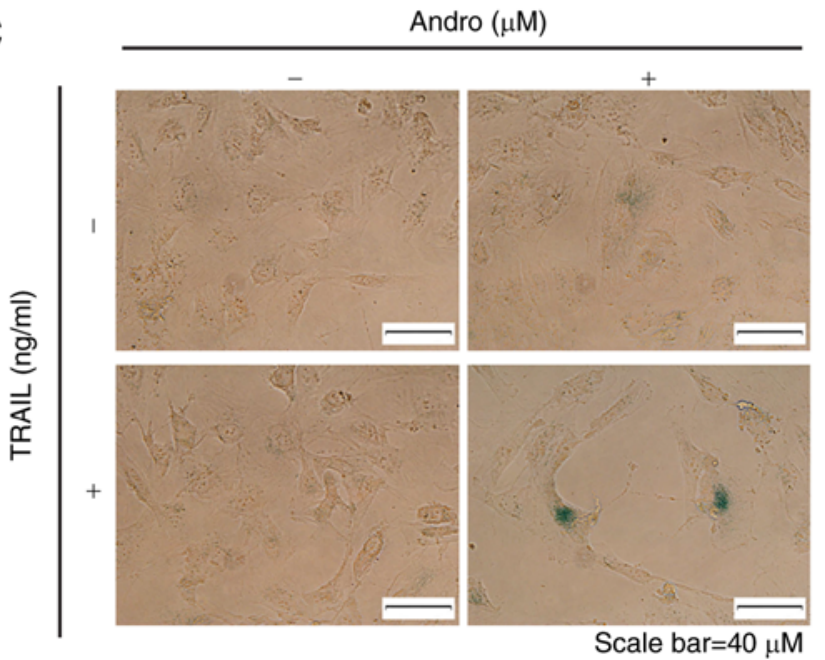

$\mathrm{D}$

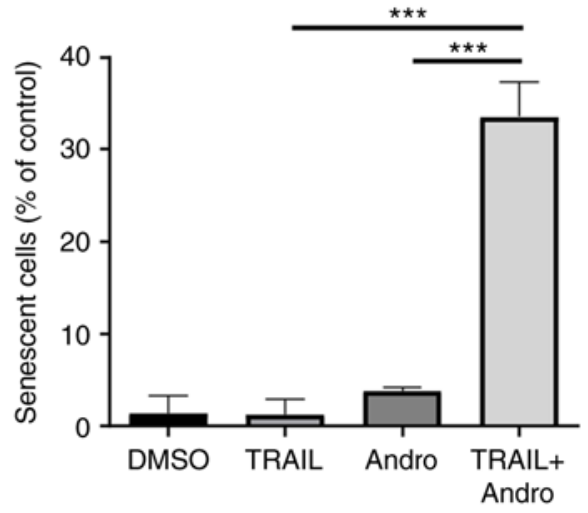

Figure 3. TRAIL combined with Andro induces G2 cell cycle arrest and senescence in 786-0 cells. (A) Cell cycle arrest by combined treatment with TRAIL $(50 \mathrm{ng} / \mathrm{ml})$ and Andro $(5 \mu \mathrm{M})$ for $24 \mathrm{~h}$. (B) The histogram shows the percentage of cells in each cell cycle phase (two-way ANOVA, Tukey). (C) Cells were treated with TRAIL $(50 \mathrm{ng} / \mathrm{ml})$ and/or Andro $(5 \mu \mathrm{M})$ for $24 \mathrm{~h}$ before being subjected to Senescence $\beta$-Galactosidase staining. Images (magnification, $\mathrm{x} 400$ ) show the senescence of 786-0 cells after the treatments. (D) The histogram indicates the percentage of senescent cells of all cells in a view (one-way ANOVA, Tukey). Data are shown as mean $\pm \mathrm{SD} ;{ }^{* * *} \mathrm{P}<0.001, \mathrm{n}=3$ ). Andro, andrographolide; TRAIL, tumor necrosis factor-related apoptosis-inducing ligand.

activation that did not involve cell necrosis. The antitumor effects of the Andro and TRAIL combined treatment was almost blocked by a pan-caspase inhibitor Z-VAD $(0.05 \mu \mathrm{M}$, $91.72 \pm 4.21 \%$ ), but not by cell-necrosis inhibitor necrostatin-1 $(0.05 \mu \mathrm{M}, 45.67 \pm 3.29 \%)$. This further confirms that Andro enhanced TRAIL-mediated caspase-dependent apoptotic cell death in RCC cells (Fig. 4C). Cell morphology was also consistent with the MTS assay results (Fig. 4D).

Andro sensitizes TRAIL-induced apoptosis via upregulation of DR4. Our immunoblot assays demonstrated that Andro treatment selectively upregulated protein levels of DR4 (Fig. 5A), but not of DR5 (Fig. 5B). To determine whether one or both receptors are responsible for the pro-apoptotic effect of TRAIL in RCC cells, we used small RNA interference to block endogenous DR4/DR5 translation according to their knockdown efficiency determined by immunoblotting (Fig. 5E). The results demonstrated that cell viability was slightly restored in the DR5-knockdown cells $(53.10 \pm 2.71 \%)$ and restored to a higher degree in the DR4-knockdown cells $(80.07 \pm 3.71 \%)$ following combination treatment with TRAIL and Andro (Fig. 5D). Cell apoptosis assays and clonogenic assays further supported the important roles of DR4 in the effects of the combined treatment of TRAIL and Andro (Fig. 5F and G).

\section{Discussion}

Renal cell carcinoma ( $\mathrm{RCC}$ ) is the third most prevalent urinary tumor and claims more than 100,000 lives each year worldwide (18). At present, the primary treatment for RCC, either localized RCC or locally advanced RCC, is surgery. However, for patients with metastatic RCC, surgery does not significantly improve the prognosis or quality of life (4). Moreover, $\mathrm{RCC}$ is neither sensitive to radiotherapy nor chemotherapy 


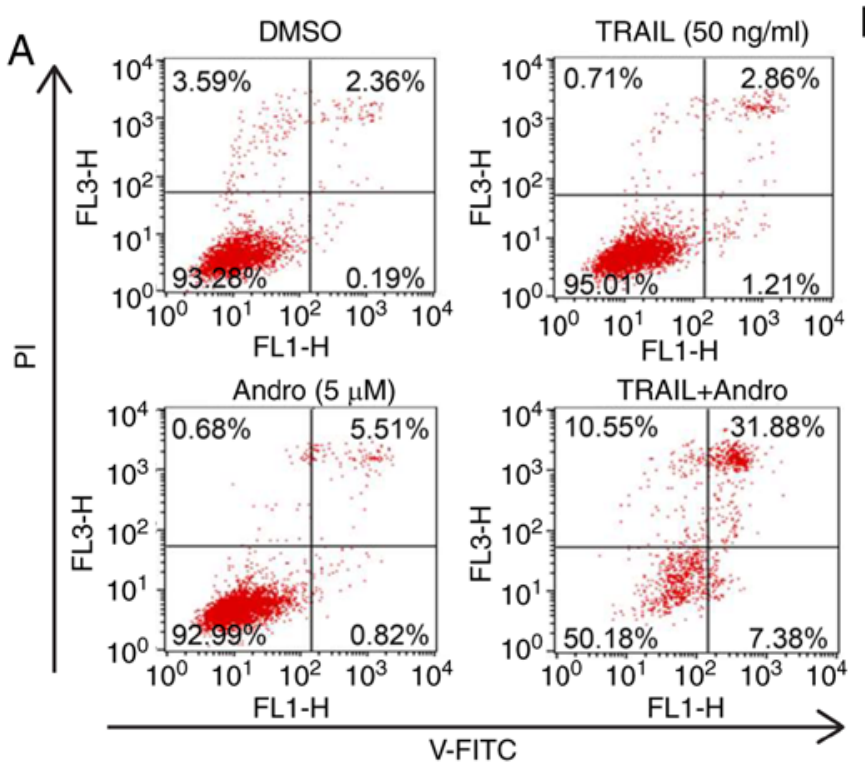

B

$\begin{array}{rcccc}\text { TRAIL }(\mathrm{ng} / \mathrm{ml}) & 0 & 50 & 0 & 50 \\ \text { Andro }(\mu \mathrm{M}) & 0 & 0 & 5 & 5 \\ 15 \mathrm{kDa} & & \end{array}$

$\gamma-\mathrm{H} 2 \mathrm{AX}$

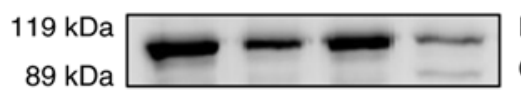

PARP1

$89 \mathrm{kDa}$

Cleaved-PARP1

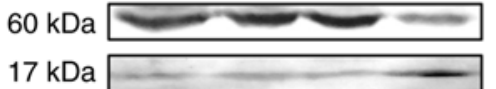

Pro-caspase-8

$17 \mathrm{kDa}$

Cleaved caspase-8

$21 \mathrm{kDa} \rightleftharpoons$ Bax

$45 \mathrm{kDa}$

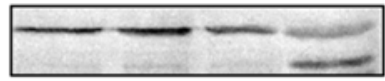

Pro-caspase-9

$35 \mathrm{kDa}$

Cleaved caspase- 9

$46 \mathrm{kDa}$

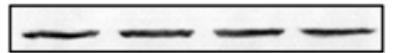

$\beta$-actin

C

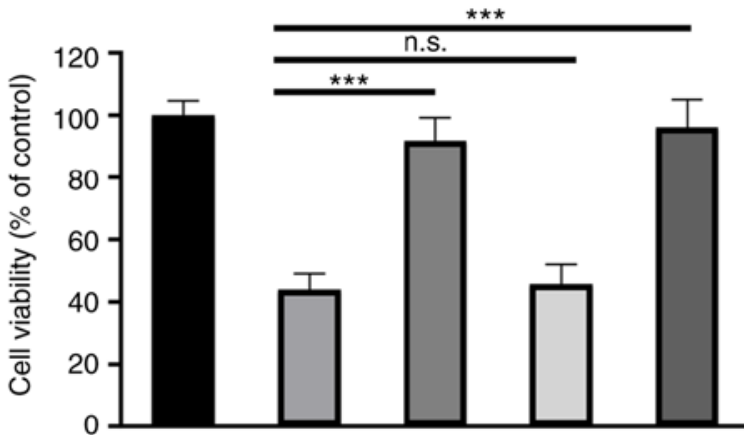

TRAIL $(50 \mathrm{ng} / \mathrm{ml})$

Andro $(5 \mu \mathrm{M})$

Z-VAD $(0.05 \mu \mathrm{M})$

Nec-1 $(0.05 \mu \mathrm{M})$

D

TRAIL $(50 \mathrm{ng} / \mathrm{ml})+$ Andro $(5 \mu \mathrm{M})$
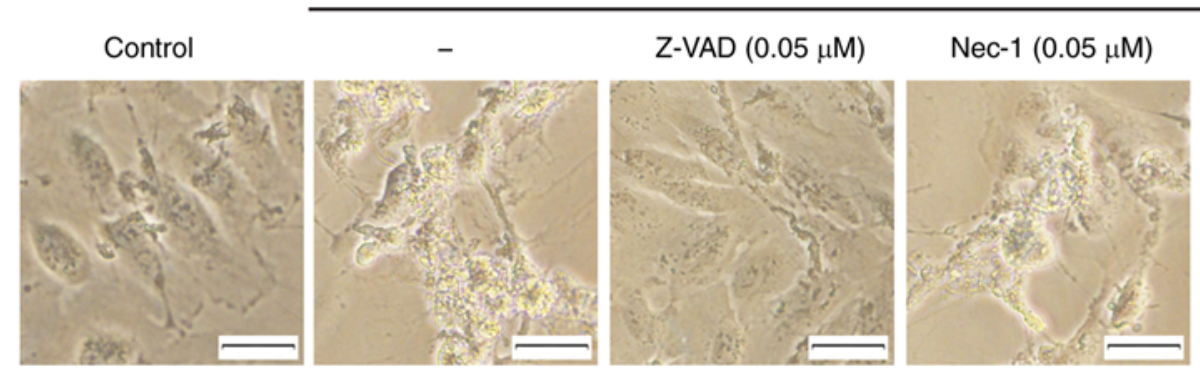

Z-VAD+Nec-1

Figure 4. Combined treatment of Andro and TRAIL induces caspase-dependent apoptosis in 786-0 cells. (A) Cell apoptosis was determined by Annexin V-FITC after DMSO, TRAIL (50 ng/ml), and/or Andro (5 $\mu \mathrm{M})$ treatment for $24 \mathrm{~h}$. (B) Indicated protein levels in 786-0 cells treated with TRAIL (50 ng/ml) and/or Andro $(5 \mu \mathrm{M})$ for $24 \mathrm{~h}$ as detected by immunoblotting. (C) Cells were treated with DMSO, TRAIL ( $50 \mathrm{ng} / \mathrm{ml})$, and Andro (5 $\mu \mathrm{M})$, pan-caspase inhibitor Z-VAD $(0.05 \mu \mathrm{M})$, and cell-necrosis inhibitor necrostatin-1 (Nec-1) $(0.05 \mu \mathrm{M})$. Then cell viability was determined by MTS assay (one-way ANOVA, Tukey). (D) Images (magnification, $\mathrm{x} 400$ ) show the apoptotic cells following treatment under different conditions. Data are shown as mean \pm SD; $\mathrm{n} . \mathrm{s}$. (not significant), $\mathrm{P}>0.05,{ }^{* * *} \mathrm{P}<0.001, \mathrm{n}=3$ ). Andro, andrographolide; TRAIL, tumor necrosis factor-related apoptosis-inducing ligand; PI, propidium iodide; PARP1, poly(ADP ribose) polymerase 1; Bax, Bcl-2 associated $\mathrm{X}$, apoptosis regulator, DR, death receptor.

and has a low response to cytokine therapy (19). Tumor necrosis factor-related apoptosis-inducing ligand (TRAIL) is a promising agent for anticancer therapy due to its ability to selectively trigger cancer cell death (20). Moreover, in contrast to other members of the TNF superfamily, TRAIL administration in vivo is harmless (21-23). However, the resistance of cancer cells to TRAIL-mediated apoptosis is a major limitation to its clinical application $(24,25)$. In the present study, we 

A TRAIL $(\mathrm{ng} / \mathrm{ml}) \quad 0 \quad 50 \quad 0 \quad 50$
Andro $(\mu \mathrm{M}) \quad 0 \quad 0 \quad 505$
$45 \mathrm{kDa}$
$36 \mathrm{kDa}$

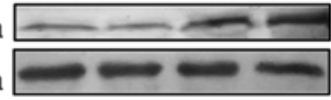
DR4
GAPDH

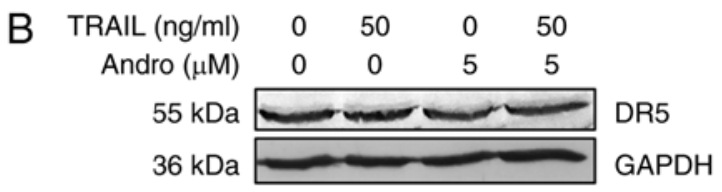

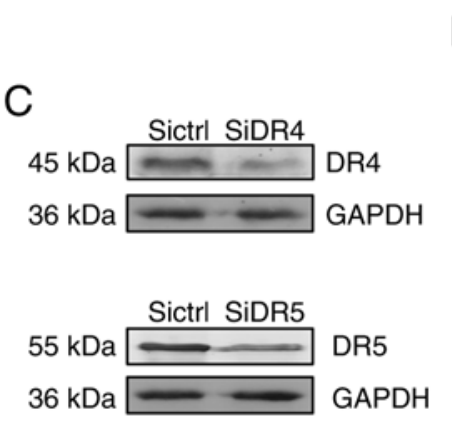

D DMSO

C

$\mathrm{F}$
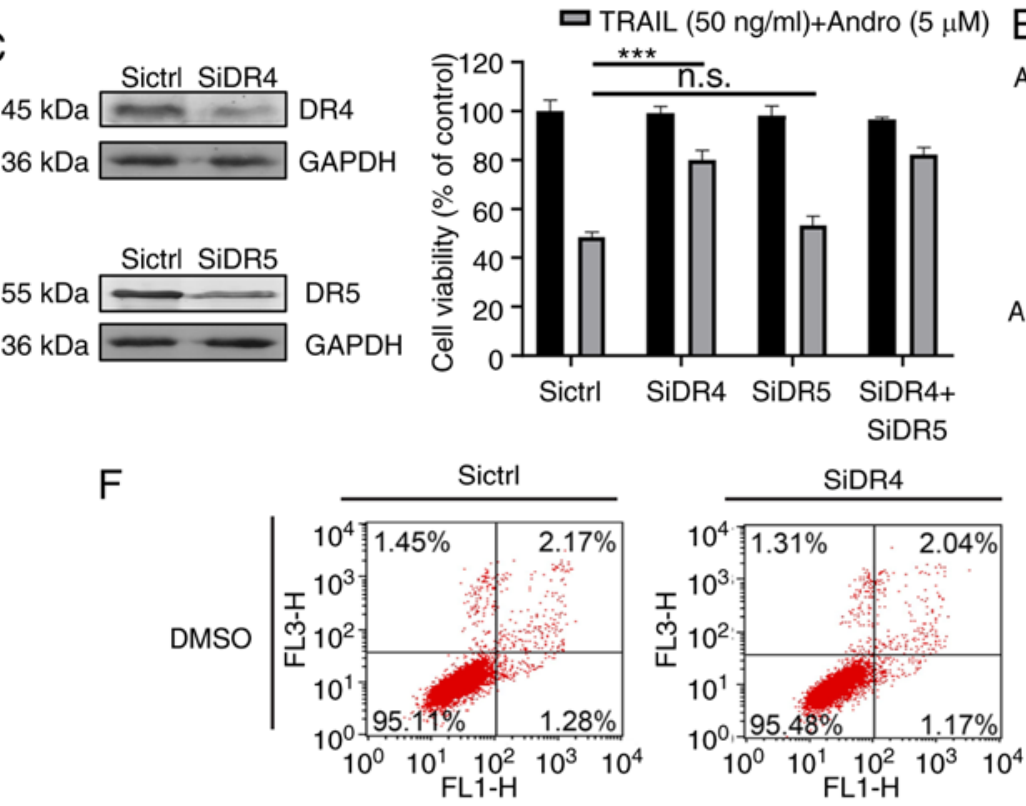

E

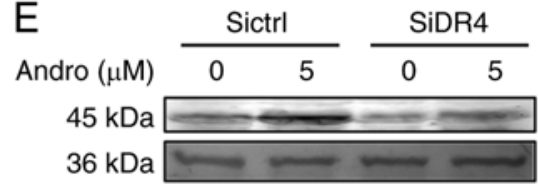

DR4
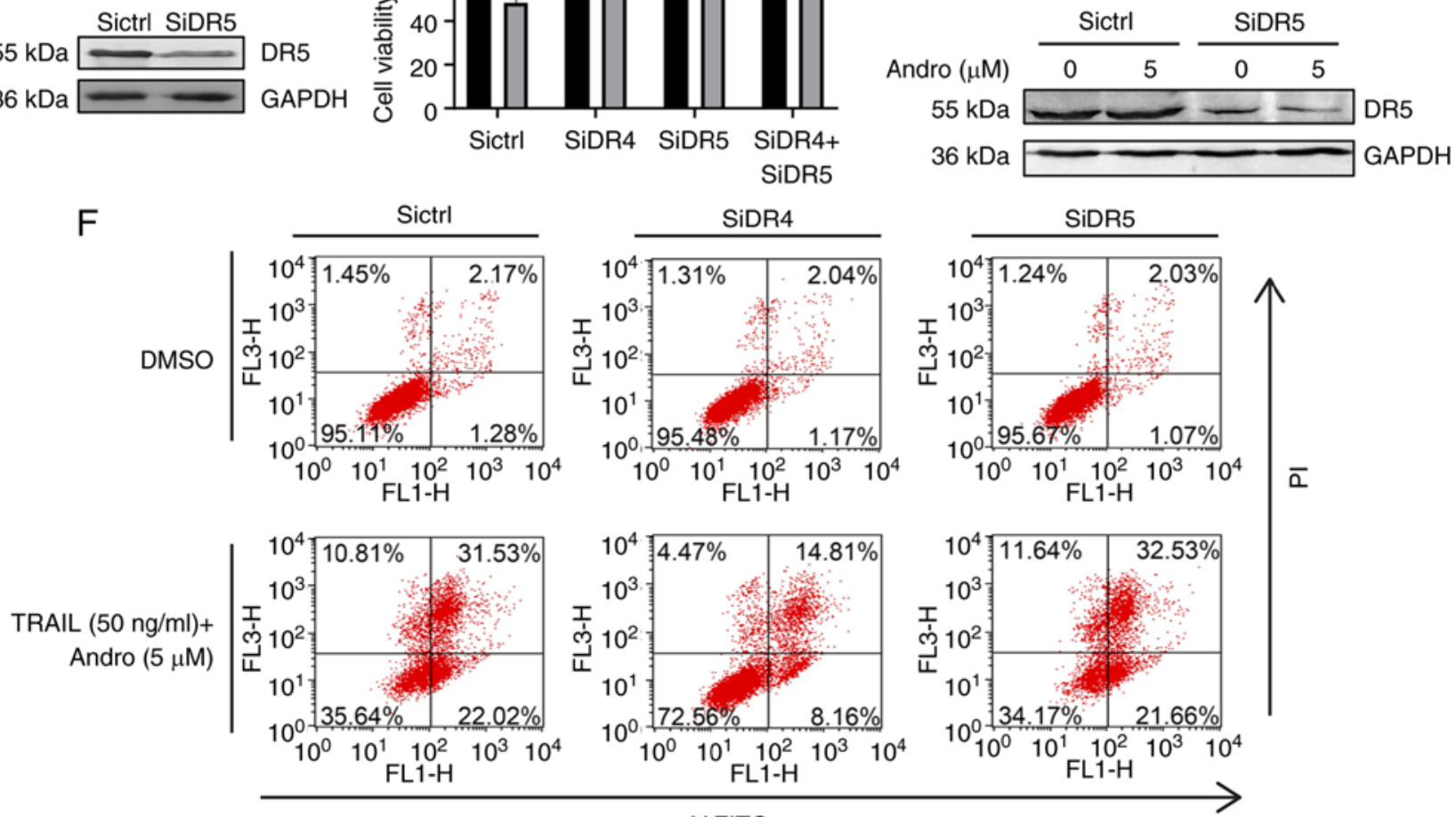

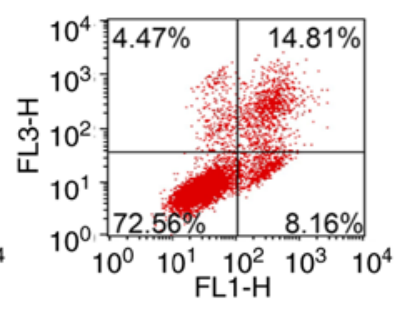

V-FITC

G
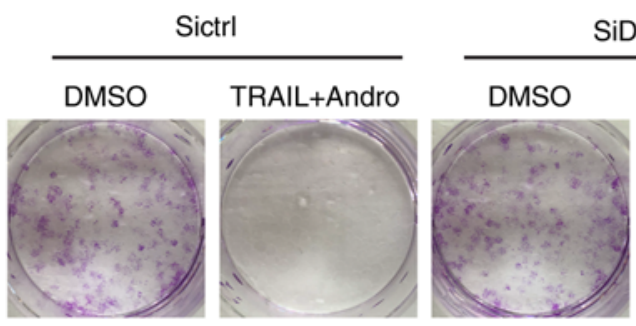

SiDR4

Figure 5. DR4 is critical for Andro-mediated sensitization of 786-0 cells to TRAIL. (A and B) DR4 and DR5 protein levels in 786-0 cells treated with TRAIL $(50 \mathrm{ng} / \mathrm{ml})$ and/or Andro $(5 \mu \mathrm{M})$ for $24 \mathrm{~h}$. (C) DR4 and DR5 protein levels in siRNA-targeted DR4 or DR5-transfected (siDR5 and siDR4) cells. (D) Cell viability of 786-0 cells transfected with siDR4 and/or siDR5 and treated with the combination of TRAIL (50 ng/ml) and Andro (5 $\mu \mathrm{M})$ for $24 \mathrm{~h}$ (two-way ANOVA, Tukey). (E) DR4 and DR5 protein levels in siRNA-targeted DR4 or DR5-transfected cells and treated with Andro (5 $\mu \mathrm{M})$ for $24 \mathrm{~h}$. (F) Cell apoptosis was determined by Annexin V-FITC after transfection with siDR4 or siDR5 and treated with the combination of TRAIL (50 ng/ml) and Andro (5 $\mu \mathrm{M})$ for $24 \mathrm{~h}$. (G) Effects of TRAIL $(50 \mathrm{ng} / \mathrm{ml})$ and Andro $(0.5 \mu \mathrm{M})$ on the clonogenic formation of 786-0 cells after transfection with siDR4 or siDR5. Data are shown as mean $\pm \mathrm{SD}$; n.s. (not significant), $\mathrm{P}>0.05,{ }^{* * * *} \mathrm{P}<0.001, \mathrm{n}=3$ ). Andro, andrographolide; TRAIL, tumor necrosis factor-related apoptosis-inducing ligand; DR, death receptor; PI, propidium iodide.

confirmed that human RCC cell lines were widely unresponsive to TRAIL-mediated cytotoxicity, which was primarily due to low expression levels of its receptor in these RCC cells. Hence, it is necessary to assess and find novel TRAIL sensitive agents with high efficacy and low toxicity.

In this preclinical study, we showed that andrographolide (Andro), a major constituent of Andrographis paniculate, an annual herbaceous plant in the family Acanthaceae, a natural compound, restored the sensitivity of RCC cell lines to TRAIL-mediated apoptosis. The findings provide critical insight into a novel therapeutic strategy for RCC patients. Andro administration enhanced TRAIL-mediated inhibition of cell viability, proliferation, migration, and colony formation of RCC cell lines. Moreover, our data revealed that 
combination therapy also potently inhibited the proliferation of diverse RCC cell lines, suggesting that Andro enhanced the anticancer activity of TRAIL independent of RCC cell type.

Most cancer cells resist apoptosis $(26,27)$. The combined treatment with TRAIL and Andro potently triggered cell cycle arrest, senescence, and apoptosis in RCCs, which largely relied on its ability to specifically increase death receptor (DR)4 expression. Elevation of membrane associated DR4 expression by Andro treatment amplified TRAIL-mediated initiation of apoptosis, cleavage of PARP1, and caspase activation. A pan-caspase inhibitor (Z-VAD-FMK), but not the necrosis inhibitor, Necrostatin-1, almost fully restored cell viability in RCC cells treated with both TRAIL and Andro, further supporting an Andro-specific increase in the cytotoxicity of TRAIL in RCC cells through its induction of caspase-dependent apoptosis. All of these results revealed that Andro treatment acts synergistically with TRAIL treatment on RCC cells.

In-depth understanding of the causes of TRAIL resistance in renal cancer may help to better develop drugs that are more effective. TRAIL binding to its receptors (DR4 and DR5) to initiate DISC assembly subsequently activates the caspase cascades and triggers apoptosis (28). Accumulating evidence suggests that an increase in TRAIL receptors is an effective strategy for enhancing the sensitivity of cancer cells to TRAIL-mediated effects (29-31). The tumor suppressor p53 is a key apoptosis regulator limiting cancer development via its proapoptotic function $(11,32)$. Transcriptional activation of death receptors by $\mathrm{p} 53$ is essential for its tumor-suppressing functions. Recently, our findings and that of other authors have demonstrated that Andro activates p53 signaling which results in DR4 or DR5 upregulation in other cancer cell types (17,33-35). It has also been known that p53 signaling stimulates the DR5 gene through an intronic sequence-specific DNA-binding site (36). In addition, previous findings that DNA damage-induced p53 activation leads to DR4 upregulation further supports the essential role of p53 signaling in the regulation of death receptors expression (37).

Interestingly, unlike our previous report that elevation of DR5 but not DR4 expression is one of the determinant factors for Andro-mediated sensitization of bladder cancer cells to TRAIL, we found that the expression levels of DR4 but not DR5 are critical for counteracting TRAIL-resistance in RCCs by Andro (17). These data hint that TRAIL signaling in diverse cancer types is selectively initiated by a certain TRAIL receptor, DR4 or DR5. Future studies need to clarify the detailed strategies of cancer cells to evade suppression by TRAIL. Furthermore, clinical database analysis revealed that a modest increase in mRNA expression levels of DR4 was noted in RCC patients which was in contrast to the dramatic elevation of DR5 mRNA levels. These results imply that the low expression of DR4 is one determinant strategy for the evasion of TRAIL proapoptosis signaling by renal cancer cells.

The potential application of andrographolide in clinical cancer treatment has several advantages $(38,39)$. Andro is widely distributed in various plants of the genus Andrographis and has been used for centuries in Asia (40). Andro possesses therapeutic effects against various conditions, such as carcinoma, arthritis, ischemia, pyrogenesis, and oxidative stress (41-44). Due to its short half-life, Andro can be excreted from the body at a high rate with almost no toxic effects to normal cells (45). Considering these features, our results indicated that Andro counteracts TRAIL resistance in RCC cells providing proof-of-concept evidence for the clinical investigation of combined treatment of TRAIL and the traditional anti-inflammatory agent, andrographolide, in renal carcinoma therapy.

\section{Acknowledgements}

We thank Guanchen Liu and Jiaxin Yang (Key Laboratory of Organ Regeneration and Transplantation of the Ministry of Education, Institute of Translational Medicine, Institute of Virology and AIDS Research, The First Hospital of Jilin University, Changchun, Jilin 130061, China) for their technical assistance.

\section{Funding}

This research was supported in part by funding from the National Natural Science Foundation of China (81772183), the Department of Science and Technology of Jilin Province (20190304033YY and 20180101127JC), the Program for JLU Science and Technology Innovative Research Team (2017TD-08) and Fundamental Research Funds for the Central Universities.

\section{Availability of data and materials}

The datasets used during the present study are available from the corresponding author upon reasonable request.

\section{Authors' contributions}

WW, CW, and YD conceived and designed the experiments. RB, YD, CT, LX, BX performed the experiments and collected and analyzed the data. WW with the help of CW and BR wrote the manuscript. All authors read and approved the manuscript and agree to be accountable for all aspects of the research in ensuring that the accuracy or integrity of any part of the work are appropriately investigated and resolved.

\section{Ethics approval and consent to participate}

This study was approved by the Ethics Committee of the First Hospital of Jilin University (Changchun, Jilin, China).

\section{Patient consent for publication}

Not applicable.

\section{Competing interests}

The authors declare that they have no competing interests.

\section{References}

1. Ferlay J, Soerjomataram I, Dikshit R, Eser S, Mathers C, Rebelo M, Parkin DM, Forman D and Bray F: Cancer incidence and mortality worldwide: Sources, methods and major patterns in GLOBOCAN 2012. Int J Cancer 136: E359-E386, 2015. 
2. Eble JN, Sauter G, Epstein JI and Sesterhenn IA (eds): World Health Organization Classification of Tumours. Pathology and genetics of tumours of the urinary system and male genital organs. IARC Press, Lyon, 2004

3. Van Poppel H, Da Pozzo L, Albrecht W, Matveev V, Bono A, Borkowski A, Colombel M, Klotz L, Skinner E, Keane T, et al: A prospective, randomised EORTC intergroup phase 3 study comparing the oncologic outcome of elective nephron-sparing surgery and radical nephrectomy for low-stage renal cell carcinoma. Eur Urol 59: 543-552, 2011.

4. Shinder BM, Rhee K, Farrell D, Farber NJ, Stein MN, Jang TL and Singer EA: Surgical management of advanced and metastatic renal cell carcinoma: A multidisciplinary approach. Front Oncol 7: 107, 2017.

5. Li P, Wong YN, Armstrong K, Haas N, Subedi P, Davis-Cerone M and Doshi JA: Survival among patients with advanced renal cell carcinoma in the pretargeted versus targeted therapy eras. Cancer Med 5: 169-181, 2016.

6. Banumathy G and Cairns P: Signaling pathways in renal cell carcinoma. Cancer Biol Ther 10: 658-664, 2010.

7. Ashkenazi A and Salvesen G: Regulated cell death: Signaling and mechanisms. Annu Rev Cell Dev Biol 30: 337-356, 2014.

8. LeBlanc HN and Ashkenazi A: Apo2L/TRAIL and its death and decoy receptors. Cell Death Differ 10: 66-75, 2003.

9. Luo X, Budihardjo I, Zou H, Slaughter C and Wang X: Bid, a $\mathrm{Bcl} 2$ interacting protein, mediates cytochrome $\mathrm{c}$ release from mitochondria in response to activation of cell surface death receptors. Cell 94: 481-490, 1998.

10. Du C, Fang M, Li Y, Li L and Wang X: Smac, a mitochondrial protein that promotes cytochrome c-dependent caspase activation by eliminating IAP inhibition. Cell 102: 33-42, 2000.

11. Jin $Z$ and El-Deiry WS: Overview of cell death signaling pathways. Cancer Biol Ther 4: 139-163, 2005.

12. Hall MA and Cleveland JL: Clearing the TRAIL for cancer therapy. Cancer Cell 12: 4-6, 2007.

13. Wang S and El-Deiry WS: TRAIL and apoptosis induction by TNF-family death receptors. Oncogene 22: 8628-8633, 2003.

14. Huang Y and Sheikh MS: TRAIL death receptors and cancer therapeutics. Toxicol Appl Pharmacol 224: 284-289, 2007.

15. Ou YC, Li JR, Kuan YH, Raung SL, Wang CC, Hung YY, Pan PH, Lu HC and Chen CJ: Luteolin sensitizes human 786-O renal cell carcinoma cells to TRAIL-induced apoptosis. Life Sci 100: 110-117, 2014.

16. Wei R,Zhu G,Jia N and Yang W: Epigallocatechin-3-gallate sensitizes human 786-O renal cell carcinoma cells to TRAIL-induced apoptosis. Cell Biochem Biophys 72: 157-164, 2015.

17. Deng Y, Bi R, Guo H, Yang J, Du Y, Wang C and Wei W: Andrographolide enhances TRAIL-induced apoptosis via p53-mediated death receptors up-regulation and suppression of the NF-KB pathway in bladder cancer cells. Int J Biol Sci 15: 688-700, 2019.

18. Zeng Z, Que T, Zhang J and Hu Y: A study exploring critical pathways in clear cell renal cell carcinoma. Exp Ther Med 7: $121-130,2014$

19. Buti S, Bersanelli M, Sikokis A, Maines F, Facchinetti F, Bria E, Ardizzoni A, Tortora G and Massari F: Chemotherapy in metastatic renal cell carcinoma today? A systematic review. Anticancer Drugs 24: 535-554, 2013.

20. von Karstedt S, Montinaro A and Walczak H: Exploring the TRAILs less travelled: TRAIL in cancer biology and therapy. Nat Rev Cancer 17: 352-366, 2017.

21. Ashkenazi A, Pai RC, Fong S, Leung S, Lawrence DA, Marsters SA, Blackie C, Chang L, McMurtrey AE, Hebert A, et al: Safety and antitumor activity of recombinant soluble Apo2 ligand. J Clin Invest 104: 155-162, 1999.

22. Walczak H, Miller RE, Ariail K, Gliniak B, Griffith TS, Kubin M, Chin W, Jones J, Woodward A, Le T, et al: Tumoricidal activity of tumor necrosis factor-related apoptosis-inducing ligand in vivo. Nat Med 5: 157-163, 1999.

23. Roberts NJ, Zhou S, Diaz LA Jr and Holdhoff M: Systemic use of tumor necrosis factor alpha as an anticancer agent. Oncotarget 2: 739-751, 2011.

24. Ahmed SM, Wu X, Jin X, Zhang X, Togo Y, Suzuki T, Li Y, Kanematsu A, Nojima M, Yamamoto S, et al: Synergistic induction of apoptosis by mapatumumab and anthracyclines in human bladder cancer cells. Oncol Rep 33: 566-572, 2015.

25. Yuan X, Gajan A, Chu Q, Xiong H, Wu K and Wu GS: Developing TRAIL/TRAIL death receptor-based cancer therapies. Cancer Metastasis Rev 37: 733-748, 2018.
26. Johnstone RW, Ruefli AA and Lowe SW: Apoptosis: A link between cancer genetics and chemotherapy. Cell 108: 153-164, 2002.

27. Hanahan D and Weinberg RA: Hallmarks of cancer: The next generation. Cell 144: 646-674, 2011

28. Chen Z, Sangwan V, Banerjee S, Chugh R, Dudeja V, Vickers SM and Saluja AK: Triptolide sensitizes pancreatic cancer cells to TRAIL-induced activation of the death receptor pathway. Cancer Lett 348: 156-166, 2014.

29. Hotta M, Sakatani T, Ishino K, Wada R, Kudo M, Yokoyama Y, Yamada T, Yoshida $\mathrm{H}$ and Naito Z: Farnesoid X receptor induces cell death and sensitizes to TRAIL-induced inhibition of growth in colorectal cancer cells through the up-regulation of death receptor 5. Biochem Biophys Res Commun 519 : 824-831, 2019.

30. Shishodia G, Koul S, Dong Q and Koul HK: Tetrandrine (TET) induces death receptors Apo Trail R1 (DR4) and Apo Trail R2 (DR5) and sensitizes prostate cancer cells to TRAIL-induced apoptosis. Mol Cancer Ther 17: 1217-1228, 2018.

31. Yang X, Li Z, Wu Q, Chen S, Yi C and Gong C: TRAIL and curcumin codelivery nanoparticles enhance TRAIL-induced apoptosis through upregulation of death receptors. Drug Deliv 24: 1526-1536, 2017.

32. Aubrey BJ, Kelly GL, Janic A, Herold MJ and Strasser A: How does p53 induce apoptosis and how does this relate to p53-mediated tumour suppression? Cell Death Differ 25: 104-113, 2018

33. Zhou J, Lu GD, Ong CS, Ong CN and Shen HM: Andrographolide sensitizes cancer cells to TRAIL-induced apoptosis via p53-mediated death receptor 4 up-regulation. Mol Cancer Ther 7: 2170-2180, 2008.

34. Wei RJ, Zhang XS and He DL: Andrographolide sensitizes prostate cancer cells to TRAIL-induced apoptosis. Asian J Androl 20: 200-204, 2018.

35. Chen M, Wang X, Zha D, Cai F, Zhang W, He Y, Huang Q, Zhuang $\mathrm{H}$ and Hua ZC: Apigenin potentiates TRAIL therapy of non-small cell lung cancer via upregulating DR4/DR5 expression in a p53-dependent manner. Sci Rep 6: 35468, 2016.

36. Takimoto R and El-Deiry WS: Wild-type p53 transactivates the KILLER/DR5 gene through an intronic sequence-specific DNA-binding site. Oncogene 19: 1735-1743, 2000.

37. Liu X, Yue P, Khuri FR and Sun SY: p53 upregulates death receptor 4 expression through an intronic p53 binding site. Cancer Res 64: 5078-5083, 2004.

38. Rajagopal S, Kumar RA, Deevi DS, Satyanarayana C and Rajagopalan R: Andrographolide, a potential cancer therapeutic agent isolated from Andrographis paniculata. J Exp Ther Oncol 3: 147-158, 2003.

39. Kumar RA, Sridevi K, Kumar NV, Nanduri S and Rajagopal S: Anticancer and immunostimulatory compounds from Andrographis paniculata. J Ethnopharmacol 92: 291-295, 2004.

40. Sabu KK, Padmesh P and Seeni S: Intraspecific variation in active principle content and isozymes of Andrographis paniculata Nees (Kalmegh): A traditional hepatoprotective medicinal herb of India. J Med Aromat Plant Sci 23: 637-647, 2001.

41. Peng T, Hu M, Wu TT, Zhang C, Chen Z, Huang S and Zhou XH: Andrographolide suppresses proliferation of nasopharyngeal carcinoma cells via attenuating NF- $\mathrm{B}$ pathway. Biomed Res Int 2015: 735056, 2015.

42. Gupta S, Mishra KP, Singh SB and Ganju L: Inhibitory effects of andrographolide on activated macrophages and adjuvant-induced arthritis. Inflammopharmacology 26: 447-456, 2018.

43. Chan SJ, Wong WS, Wong PT and Bian JS: Neuroprotective effects of andrographolide in a rat model of permanent cerebral ischaemia. Br J Pharmacol 161: 668-679, 2010.

44. Li B, Jiang T, Liu H, Miao Z, Fang D, Zheng L and Zhao J: Andrographolide protects chondrocytes from oxidative stress injury by activation of the Keap1-Nrf2-Are signaling pathway. J Cell Physiol 234: 561-571, 2018.

45. Jaruchotikamol A, Jarukamjorn K, Sirisangtrakul W, Sakuma T, Kawasaki Y and Nemoto N: Strong synergistic induction of CYP1A1 expression by andrographolide plus typical CYP1A inducers in mouse hepatocytes. Toxicol Appl Pharmacol 224: $156-162,2007$.

This work is licensed under a Creative Commons Attribution-NonCommercial-NoDerivatives 4.0 International (CC BY-NC-ND 4.0) License. 